\title{
Prospects for Using Bacteriocins of Normal Microbiota in Antibacterial Therapy (Review)
}

DOI: $10.17691 / \mathrm{stm} 2019.11 .3 .17$

Received June 29, 2018

M.., Zaslayskaya, DSc, Associate Professor, Professor, Department of Epidemiology, Microbiology

and Evidence-Based Medicine 1 ;

T.V. Makhrova, MD, PhD, Associate Professor, Department of Epidemiology, Microbiology and Evidence-Based Medicine\%,

N.A. Aleksandrova, PhD, Senior Teacher, Department of Epidemiology, Microbiology and Evidence-Based Medicine";

N.I. Ignatova, PhD, Associate Professor, Department of Epidemiology, Microbiology and Evidence-Based Medicine ${ }^{1}$;

I.V. Belova, PhD, Leading Researcher, Laboratory of Human Microbiome Research and Correction;

A.G. Tochilina, PhD, Senior Researcher, Laboratory of Human Microbiome Research and Correction; I.V. Solovyeva, DSc, Head of the Laboratory of Human Microbiome Research and Correction ${ }^{2}$

${ }^{1}$ Privolzhsky Research Medical University, 10/1 Minin and Pozharsky Square, Nizhny Novgorod, 603005, Russia; ${ }^{2}$ Blokhina Scientific Research Institute of Epidemiology and Microbiology of Nizhny Novgorod, Federal Service for Surveillance on Consumer Rights Protection and Human Wellbeing (Rospotrebnadzor), 44 Gruzinskaya St., Nizhny Novgorod, 603950, Russia

Increasing resistance of microorganisms to antibiotics has encouraged researchers to seek alternative antimicrobial therapy. The review studies the prospects for using bacteriocins as antibacterial drugs. The definition of bacteriocins is given and their difference from traditional antibiotics is explained. The modern classification of bacteriocins, their properties and mechanisms of action are presented. Examples of the main bacteriocin-producing bacteria representing normal human microbiota are given. The authors investigate the role of bacteriocins produced by microbiota in maintaining mucosal resistance and stabilizing the human microbiome as well as the possibility of their application in creating probiotic drugs. The advantages and disadvantages of bacteriocins as alternative antibacterial drugs are described. The applications of bacteriocins in antimicrobial therapy, as well as methods for their industrial manufacturing, are discussed.

Key words: bacteriocins; antimicrobial therapy; normal human microbiota.

\section{Introduction}

A sharp increase in bacterial resistance to antibiotics $[1,2]$ poses difficulty in conducting effective antimicrobial therapy. Besides, side effects of antibiotics, such as cytotoxicity, suppression of normal human microbiota, the likelihood of allergic and autoimmune diseases can also impose restrictions on the use of these drugs [3, 4]. All this necessitates the search for new approaches and treatment regimens for infectious diseases [2, 5]. The use of bacteriocins in alternative or combined antimicrobial therapy seems to be a possible solution to this problem $[6,7]$.

\section{Classification of bacteriocins and their mechanisms of action}

Bacteriocins are a large group of peptides secreted by individual bacteria with antimicrobial activity. In contrast of antibiotics acting as antimetabolites, bacteriocins cause damage to bacterial cell structures and subsequent cell death [7-13]. Such peptides are produced by most species of bacteria, though this ability is strain-dependent [7]. The biocidal effect of these peptides is likely to manifest itself not only in strains of the same species, but also in representatives of other species and genera. The range of antimicrobial activity of bacteriocins is somewhat narrower than that of antibiotics as it is determined by presence of receptors for their adsorption in target bacteria [14].

Bacteriocins are classified based on several characteristics: the primary molecular structure, molecular weight, the presence of post-translational modifications, physical and chemical properties, the range of antimicrobial activity, the mechanism of antimicrobial action, receptors of target cells and genetic characteristics $[7,8,13-17]$. There are three main classes of bacteriocins (Table 1). Notably, bacteria of the same strain are able to secrete bacteriocins belonging to different classes. 
Table 1

Functional classification of bacteriocins and their possible mechanisms of action

\begin{tabular}{|c|c|c|}
\hline Bacteriocins & Receptor variants & Possible action on the target cell \\
\hline $\begin{array}{l}\text { Class I - post-translationally modified } \\
\text { Subclasses: } \\
\text { lantibiotics } \\
\text { sactibiotics, etc. } \\
\text { These are heat-resistant peptides } \\
\text { with molecular weight less than } 10 \mathrm{kDa}\end{array}$ & $\begin{array}{l}\text { In some cases, the receptor } \\
\text { is a precursor of peptidoglycan, } \\
\text { lipid II }\end{array}$ & $\begin{array}{l}\text { Formation of pores } \\
\text { in the bacterial membrane, } \\
\text { inhibition of bacterial enzyme } \\
\text { activity }\end{array}$ \\
\hline $\begin{array}{l}\text { Class II - unmodified, or cyclic } \\
\text { Subclasses: } \\
\text { Ila-Ile } \\
\text { These are heat-resistant peptides } \\
\text { with molecular weight less than } 10 \mathrm{kDa}\end{array}$ & $\begin{array}{l}\text { Class Ila bacteriocins bind } \\
\text { with the receptor } \\
\text { of mannose phosphotransferase }\end{array}$ & $\begin{array}{l}\text { Increased membrane } \\
\text { permeability due to formation } \\
\text { of ion-selective pores }\end{array}$ \\
\hline $\begin{array}{l}\text { Class III } \\
\text { Subclasses: } \\
\text { IIla, IIIb } \\
\text { These are thermolabile proteins } \\
\text { with molecular weight more than } 30 \mathrm{kDa}\end{array}$ & Underexplored & $\begin{array}{l}\text { Cleavage of bacterial cell wall } \\
\text { peptidoglycan, ATP release } \\
\text { from cells }\end{array}$ \\
\hline
\end{tabular}

Among class I bacteriocins, lantibiotics are the most well studied group. They are post-translational modified antimicrobial peptides of small size $(<5 \mathrm{kDa})$ characterized by unusual amino acids: lanthionine (Lan), a-methillothionine (MeLan), dehydroalanine, and dehydroretinol [18]. When intramolecular bonds are formed, their serine and threonine residues dehydrate to dehydroalanine and dihydrobetulin respectively [7].

Class I molecules can be grouped as type A or B according to their chemical structure and antimicrobial action [18]. Type A lantibiotics are positively charged elongated screw-shaped peptides with the average molecular weight of 2-4 kDa. The shape and charge of type A molecules facilitate formation of pores in membranes and depolarization of the latter in sensitive bacterial cell species, which leads to their lysis [16]. Type B lantibiotics (2-3 kDa) are globular peptides with negative or neutral charge. These peptides exhibit antimicrobial activity through cell lysis and inhibition of major bacterial enzymes [19-23]. Type B lantibiotics increase membrane permeability and reduce ATPdependent transport of proteins and ATP-dependent calcium absorption in sensitive bacterial cells, which results in cytolysis [24].

Class II bacteriocins are small $(<10 \mathrm{kDa})$, heatstable peptides containing no lanthionine. They can be subdivided into subgroups a, b, c, d, e based on amino acid sequences and functions. Subclass Ila bacteriocins kill target cells by increasing the cell membrane permeability, which causes release of cytoplasmic components through the membrane and cell death. Subclass Ilb bacteriocins act as pore-forming peptides [25]. Subclass IIc peptides have different mechanisms of action on membrane permeability and cell wall formation in bacteria [26], while subclass Ild bacteriocins are linear, single-peptide molecules with similar antimicrobial activity.
Class III bacteriocins consist of proteins with high molecular weight $(>30 \mathrm{kDa})$. This class is subdivided into subclasses IIla and IIIb. Subclass IIla (bacteriolysins) includes peptides destroying bacterial cell membranes, thus causing lysis and subsequent cell death [27]. Subclass IIlb comprises peptides that do not damage the potential of target cell membrane. Target cell death occurs not by cytolysis, but due to ATP outflow [16].

Bacteriocins can be identified according to the specific name of bacteria producing them: e.g., Escherichia coli synthesizes colicins, enterocins are produced by Enterococcus spp., etc. However, many of the molecules have their own original names: nisin, mersacidin, etc.

\section{Bacteriocins of normal microbiota and their significance for the human microbiome}

Bacteria of normal microbiota, representatives of the microbiome, are a permanent source of bacteriocin production, playing a significant role in human life. Microbiota forms colonization resistance barrier limiting contamination of the mucous membranes by pathogenic and non-resident opportunistic microorganisms, it is involved in stimulation of lymphoid tissue, vitamin formation, etc. [28].

In recent years, the concept of "co-immunity" has gained popularity. It suggests that a macroorganism can be protected by both its own immune system and components of its normal microbiota [29]. Representatives of the human microbiome producing bacteriocins have an ecological advantage over other strains in vivo, which indicates the significant role of these antimicrobial peptides in formation of an ecological niche [30]. Differences in specific composition of biotopes affect the density of secretion and the types of bacteriocins found in different parts of the human 
Table 2

Examples of bacteriocins produced by enterococci, lactobacilli, and bifidobacteria

\begin{tabular}{|c|c|c|c|}
\hline $\begin{array}{c}\text { Groups of } \\
\text { bacteriocins }\end{array}$ & Enterococci & Lactobacilli & Bifidobacteria \\
\hline \multicolumn{4}{|c|}{ Class I } \\
\hline Lantibiotics & $\begin{array}{l}\text { Cytolysin } \\
\text { Enterocin W }\end{array}$ & $\begin{array}{l}\text { Lactocin S } \\
\text { Carnocin U149 } \\
\text { Plantaricin W } \\
\text { Lacticin } 3147 \\
\text { Lactocin B } \\
\text { Amylovarin } \\
\text { Thermophylin A }\end{array}$ & $\begin{array}{l}\text { Bisin } \\
\text { Thermophilicin B67 } \\
\text { Bifilong }\end{array}$ \\
\hline \multicolumn{4}{|c|}{ Class II } \\
\hline Subclass Ila & $\begin{array}{l}\text { Enterocin A } \\
\text { Enterocin SE-K4 } \\
\text { Enterocin CRL-35 }\end{array}$ & $\begin{array}{l}\text { Sakacin A } \\
\text { Sakacin } 674 \\
\text { Curvacin A } \\
\text { Plantarcin } 423 \\
\text { Sakacin G }\end{array}$ & $\begin{array}{l}\text { Bifidin } \\
\text { Bifidin } 1 \\
\text { Bifidocin B } \\
\text { Bificin C6165 }\end{array}$ \\
\hline Subclass IIb & $\begin{array}{l}\text { Enterocin } 1071 \\
\text { Enterocins L50 } \\
\text { Enterocins C }\end{array}$ & $\begin{array}{l}\text { Plantaricin E/F } \\
\text { Plantaricin J/K } \\
\text { Plantaricin NC8 }\end{array}$ & \\
\hline Subclass IIc & $\begin{array}{l}\text { Enterocin B } \\
\text { Enterocin P }\end{array}$ & & \\
\hline Subclass IId & $\begin{array}{l}\text { Bacteriocin } 31 \\
\text { Enterocin I } \\
\text { Bacteriocin AS-48 }\end{array}$ & & \\
\hline \multicolumn{4}{|c|}{ Class III } \\
\hline Subclasses IIla, IIIb & Enterolisin $\mathrm{A}$ & Helviticin J & $\begin{array}{l}\text { Bifilong Bb-46 } \\
\text { Bifilact Bb-12 }\end{array}$ \\
\hline
\end{tabular}

body. The highest concentration of bacteriocins was revealed in samples from the vagina, the respiratory tract, and the oral cavity, while intestinal samples showed the lowest concentration [31]. Bacteriocins are believed to allow indigenous commensal bacteria to occupy several ecological niches as well as establish long-term relationships with other representatives of the biocenosis and commensal relationships with the host [31]. Regulation of a bacteriocin production system may be pheromone-dependent [16, 32]. A bacteriocin peptide can function as a pheromone inducing its own production. When bacterial cell density becomes high, the auto-induction loop is activated and bacteriocins are produced in high concentrations [16]. Thus, these peptides are synthesized intensively to affect similar species only when the bacterial density in the biotope is high enough to inhibit the growth of competitive strains. Production of bacteriocins in biofilms also suggests balanced competition and coexistence of organisms in a microbial community [33].

Bacteriocin synthesis by representatives of normal microbiota is considered to be one of the mechanisms of quorum sensing, which allows bacteria to communicate, coordinate their actions and synchronize group behavior through secretion of diffusing signal molecules [34].
In the process, strains producing "weak" bacteriocins have greater chances of survival in the biotope: they are less toxic to competitors, cause mild expression of bacteriocins on the part of the latter, which results in controlled competition and development of dynamic equilibrium in the population [35-38]. This fact may also explain the predominance of weak bacteriocin producers in nature [35].

Among the representatives of the human obligate microbiota, the range of bacteriocins from lactic acid bacteria of Lactobacillus, Bifidobacterium, and Enterococcus genera (lactobacilli, bifidobacteria, enterococci) [10, 15, 39-43] and from Escherichia coli [44] have been quite well-studied so far (Table 2).

Lactic acid bacteria of normal microbiota are most often the basis for the selection of strains in production of various probiotics [45-50]. Recently, metabiotics (preparations developed on the basis of the structural components of microbial cells, metabolites and signal molecules of probiotic strains and devoid of potential pathogenicity and other imperfections inherent in living bacteria) have been actively introduced into medical practice [51]. In production of various probiotic drugs and functional food products, it is considered preferable to use strains with a good ability to synthesize bacteriocins. These inhibit pathogens directly, they are able to modulate the composition of the microbiota positively and stimulate the host immune system $[52,53]$.

\section{Advantages and disadvantages of bacteriocins as antibacterial agents}

Bacteriocins have a number of advantages as antimicrobial substances. Unlike antibiotics suppressing metabolism and synthesis processes in bacteria, the action of bacteriocins is often accompanied by damage to the structures and death of the target cell, which reduces the possibility of microbial resistance. Besides, using bacteriocins is potentially advantageous due to their high biological activity (bacteriocins are efficacious in the nanomolar range) as well as low toxicity (except cytolysin) [54]. Unlike antibiotics, bacteriocins are completely metabolized in the human body, which determines their low toxicity. All this makes the use of these peptides more preferable than antibiotics in some cases $[55,56]$.

The advantages of bacteriocins also include their protein nature, which allows obtaining these peptides through bioengineering [57]. Bioengineering products are likely to have increased biological activity against 
certain pathogens as well as improved physical and chemical properties (solubility, resistance to protease and $\mathrm{pH}$ changes), which further increases their value and efficacy as antimicrobials.

However, bacteriocins, despite great potential for use in clinical practice, have a number of disadvantages. It should be remembered that bacteriocins undergo proteolytic degradation when administered orally. Nevertheless, it is possible to eliminate this defect by using encapsulation technology or parenteral administration of the drug [57]. In addition, efficacy of some lantibiotics is likely to decrease due to their instability in conditions of fluctuating neutral and alkaline $\mathrm{pH}$ values, but the way to solve the problem is obtaining substances with increased stability by means of bioengineering [58].

It should be noted that bacteria are able to develop resistance to bacteriocins $[59,60]$. Several mechanisms of bacterial resistance to lantibiotics have been described [61-66]. There are data on development of resistance to class II bacteriocins in laboratory setting [67].

Rather narrow spectrum of antimicrobial action is also able to limit the use of bacteriocins in clinical practice. It is possible to compensate for this disadvantage partially or completely when using bacteriocins in combination with other existing antimicrobials such as antibiotics.

\section{Possibilities of using bacteriocins in antimicrobial therapy}

Bacteriocins can be used to inhibit both exogenous microorganisms and the indigenous human microbiota. In particular, the possibility is considered of using bacteriocins in targeted (molecularly targeted) therapy for selective inhibition of polyresistant endogenous (auto) strains of microbiota in order to prevent antibioticresistant opportunistic infections difficult or impossible to treat [68].

Bacteriocins have their own antimicrobial potential that can be realized in treatment of infectious diseases [69]. However, combining these peptides with other existing antimicrobials is believed to be optimal in their clinical use [57]. The use of "bacteriocin-antimicrobial" combinations is expected to help enhance the microbicidal effect and thereby reduce the likelihood of developing resistance to both bacteriocin and antibiotic [57]. Notably, the antimicrobial effect of the combined medication is achieved owing to the fact that the subcomponents may have different mechanisms of antimicrobial action aimed at the same or different targets. Combinatorial therapy with bacteriocins can both broaden the antimicrobial spectra (which may be useful in treating infections of unknown etiology) and diminish or eliminate adverse side effects completely by reducing the concentration of antibiotic $[70,71]$. In the latter case, synergistic combinations of bacteriocins and antibiotics will also help to reduce costs associated with the use of expensive antibiotics.
An important factor influencing the maximum efficacy of treatment with a combination of two drugs is the way they are administered. Pharmacokinetic properties of both antimicrobials should be taken into account to optimize the delivery method of bacteriocins in combination with antibiotics. For example, it should be noted that systemically applied lantibiotics are likely to be bound by plasma proteins [72], therefore, distribution and subsequent bioavailability of bacteriocins in the area of inflammation may be significantly weakened. At the same time, localized cutaneous, intravaginal or inhaled routes of bacteriocin administration may be more effective due to the relatively low absorption rates and minimization of undesirable systemic side effects [73-75].

Data have been accumulated, concerning the effect of bacteriocins combined with various antimicrobial agents against clinical isolates (pathogens). Studies show that different combinations of bacteriocins and antimicrobials exhibit synergism [76-78], antagonism [79] or no influence on the ultimate result (indifferent effect) [80]. To predict clinical efficacy of bacteriocin-antimicrobial combinations, it is necessary to understand physical and chemical character of interactions (hydrophobichydrophobic or cationic-anionic interactions) between bacteriocin and antibiotic. Due attention should be paid to the molecular weight of components: perhaps a combination of two substances with the same molecular weight can be more efficacious than combining a highmolecular substance with a low-molecular one [57].

When selecting an effective combination of bacteriocin and antibiotic, it should be understood that the mechanism of antimicrobial action can be changed and clinical outcomes may appear difficult to predict when combining two antimicrobials. In this regard, finding successful synergistic interactions using genomic, proteomic and other modern research methods is likely to boost introduction of antimicrobial combinations in clinical practice, generally contributing to the development of alternative therapeutic options and solution of the global problem of antibiotic resistance [57, 81-84].

It should be noted that bacteria present in a biofilm are more resistant to antimicrobials than those present in a planktonic state. Biofilms are known to be composed of bacteria incorporated into the complex organic polymeric matrix impeding penetration of the antimicrobial into the deepest strata [85-87]. Thus, there is increased importance of seeking alternative therapeutic options and/or effective antimicrobial combinations to target microbial biofilm communities. Researchers have revealed an increase in anti-biofilm activity of enterococcal bacteriocins in combination with a number of antimicrobial drugs against Methicillin Resistant Staphylococcus Aureus (MRSA) [76, 88-91].

A potential strategy of abandoning traditional antibiotics may also involve combining bacteriocins with phages and/or endolysins. For example, a number of 
researchers found a synergistic effect resulting from the combined application of these substances [92-98].

Thus, considerable information about the positive effect of combined application of bacteriocins with antimicrobial drugs is available at present. This suggests that the use of bacteriocins for treatment against antibiotic-resistant strains has real prospects [99].

\section{Recent methods of bacteriocin production}

Today, bacteriocins are most often produced by selection of producer bacteria or by chemical synthesis.

The main stages of the biological pathway (selection) are: isolation of cultures from natural sources, comparative assessment of producer activity and selection of the most promising producers, experimental enhancement of producer activity, including classical methods of mutagenesis and genetic engineering techniques [49, 100, 101]. However, large-scale commercial introduction of this method to produce bacteriocins may be limited by low output (if several purification methods are used) or low purity (with a higher output), which affects the cost or quality of the product.

Current development of peptide synthesis methods allows obtaining bacteriocins chemically [102]. Chemical synthesis is generally more appropriate and efficient in production of low molecular weight peptides ( $<6 \mathrm{kDa})$. Streamlined synthesis aims at obtaining various modifications of known bacteriocins with improved properties as well as creating new drugs with desired properties. The chemical method offers many advantages such as the possibility of quick amino acid replacement, the use of modifications of the main or lateral chains in the molecule, which is likely to improve efficacy and stability giving the opportunity to change bacteriocin activity spectra. Besides, steady decline in the cost of reagents for synthesis also makes the chemical method more attractive and competitive [102].

\section{Conclusion}

In view of the increasing number of antibioticresistant strains among pathogenic and opportunistic microorganisms, the study of bacteriocins as alternative antimicrobial substances is quite timely. Non-toxicity, biological safety and the possibility to combine bacteriocins with other antimicrobial agents (antibiotics, bacteriophages, etc.) offer the challenge of using them as mono- or combined drugs for antimicrobial therapy. Given the huge potential of bacteriocins and increasing demand for them, it is extremely timely to develop methods of selection and subsequent chemical synthesis.

Representatives of the normal human microbiota are among the safest sources of bacteriocins. These peptides are involved in the mechanisms of antagonistic activity within the microbiome to maintain it in a state of dynamic equilibrium. The capacity to produce bacteriocins is an important characteristic of probiotic strains, should be considered when creating probiotics for correction of dysbiotic conditions.

Study funding. This study was not supported by any financial sources.

Conflict of interests. The authors have no conflict of interests to disclose.

\section{Rererences}

1. World Health Organization. Antimicrobial resistance: global report on surveillance. Geneva; 2014. URL: http://www. who.int/drugresistance/documents/surveillancereport/en/.

2. Holmes A.H., Moore L.S., Sundsfjord A., Steinbakk M., Regmi S., Karkey A., Guerin P.J., Piddock L.J. Understanding the mechanisms and drivers of antimicrobial resistance. Lancet 2016; 387(10014): 176-187, https://doi.org/10.1016/s01406736(15)00473-0.

3. Blaser M. Antibiotic overuse: stop the killing of beneficial bacteria. Nature 2011; 476(7361): 393-394, https:// doi.org/10.1038/476393a.

4. Willing B.P., Russell S.L., Finlay B.B. Shifting the balance: antibiotic effects on host-microbiota mutualism. Nat Rev Microbiol 2011; 9(4): 233-243, https://doi.org/10.1038/ nrmicro2536.

5. Michael C.A., Dominey-Howes D., Labbate M. The antimicrobial resistance crisis: causes, consequences, and management. Front Public Health 2014; 2: 145, https://doi. org/10.3389/fpubh.2014.00145.

6. Valyshev A.V., Valysheva N.A. Combination of antibiotics and bacteriocins - effective way for fighting resistance microorganisms. Byulleten' Orenburgskogo nauchnogo tsentra UroRAN (elektronnyy zhurnal) 2016; 4: 1-6.

7. Cotter P.D., Ross R.P., Hill C. Bacteriocins - a viable alternative to antibiotics? Nat Rev Microbiol 2013; 11(2): 95105, https://doi.org/10.1038/nrmicro2937.

8. Ermolenko E.I. Bacteriocins of enterococci, problems and perspectives of using. Vestnik Sankt-Peterburgskogo universiteta. Meditsina 2009; 3: 78-93.

9. Ermolenko E.I., Chernysh A.Yu., Berlov M.N., Totolyan A.A., Suvorov A.N. Antagonistic activity of enterococci against Streptococcus pyogenes. Vestnik SanktPeterburgskogo universiteta. Meditsina 2008; 3: 137-144.

10. Stoyanova L.G., Ustyugova E.A., Netrusov A.I. Antibacterial metabolites of lactic acid bacteria: their diversity and properties. Appl Biochem Microbiol 2012; 48(3): 229-243, https://doi.org/10.1134/s0003683812030143.

11. Sultimova T.D., Zakharov E.V. Bacteriocins of lactic acid bacteria. Vestnik VSGUTU 2016; 2(59): 41-47.

12. Breukink E., de Kruijff B. Lipid II as a target for antibiotics. Nat Rev Drug Discov 2006; 5(4): 321-332, https:// doi.org/10.1038/nrd2004.

13. Enterococci: from commensals to leading causes of drug resistant infection. Gilmore M.S., Clewell D.B., Ike Y., Shankar N. (editors). Boston: Massachusetts Eye and Ear Infirmary; 2014.

14. Blinkova L.P., Altshuler M.L., Dorofeeva E.S., Gorobets O.B. Molecular basis of bacteriocins production and activity. Zhurnal mikrobiologii epidemiologii i immunobiologii 2007; 2: 97-104. 
15. Mokoena M.P. Lactic acid bacteria and their bacteriocins: classification, biosynthesis and applications against uropathogens: a mini-review. Molecules 2017; 22(8): 1255, https://doi.org/10.3390/molecules22081255.

16. Engevik M.A. Versalovic J. Biochemical features of beneficial microbes: foundations for therapeutic microbiology. Microbiol Spectr 2017; 5(5): 3-47, https://doi.org/10.1128/ microbiolspec.BAD-0012-2016.

17. Nishie M., Nagao J., Sonomoto K. Antibacterial peptides "bacteriocins": an overview of their diverse characteristics and applications. Biocontrol Sci 2012; 17(1): 1-16, https://doi. org/10.4265/bio.17.1.

18. Guder A., Wiedemann I., Sahl H.G. Posttranslationally modified bacteriocins - the lantibiotics. Biopolymers 2000; 55(1): 62-73, https://doi.org/10.1002/10970282(2000)55:1<62::aid-bip60>3.3.co;2-p.

19. Field D., Begley M., O'Connor P.M., Daly K.M., Hugenholtz F., Cotter P.D., Hill C., Ross R.P. Bioengineered nisin A derivatives with enhanced activity against both gram positive and gram negative pathogens. PLoS One 2012; 7(10): e46884, https://doi.org/10.1371/journal.pone.0046884.

20. Field D., Daly K., O'Connor P.M., Cotter P.D., Hill C., Ross R.P. Efficacies of nisin $A$ and nisin $V$ semipurified preparations alone and in combination with plant essential oils for controlling Listeria monocytogenes. Appl Environ Microbiol 2015; 81(8): 2762-2769, https://doi.org/10.1128/aem.00070-15.

21. Field D., O' Connor R., Cotter P.D., Ross R.P., Hill C. In vitro activities of nisin and nisin derivatives alone and in combination with antibiotics against Staphylococcus biofilms. Front Microbiol 2016; 7: 508, https://doi.org/10.3389/ fmicb.2016.00508.

22. Field D., Seisling N., Cotter P.D., Ross R.P., Hill C. Synergistic nisin-polymyxin combinations for the control of Pseudomonas biofilm formation. Front Microbiol 2016; 7: 1713, https://doi.org/10.3389/fmicb.2016.01713.

23. Jabés D., Brunati C., Candiani G., Riva S., Romanó G., Donadio S. Efficacy of the new lantibiotic NAl107 in experimental infections induced by MDR gram positive pathogens. Antimicrob Agents Chemother 2011; 55(4): 16711676, https://doi.org/10.1128/aac.01288-10.

24. McAuliffe O., Ross R.P., Hill C. Lantibiotics: structure, biosynthesis and mode of action. FEMS Microbiol Rev 2001; 25(3): 285-308, https://doi.org/10.1016/s0168-6445(00) 00065-6.

25. Balla E., Dicks L.M., Du Toit M., Van Der Merwe M.J., Holzapfel W.H. Characterization and cloning of the genes encoding enterocin 1071A and enterocin 1071B, two antimicrobial peptides produced by Enterococcus faecalis BFE 1071. Appl Environ Microbiol 2000; 66(4): 1298-1304, https:// doi.org/10.1128/aem.66.4.1298-1304.2000.

26. González C., Langdon G.M., Bruix M., Gálvez A., Valdivia E., Maqueda M., Rico M. Bacteriocin AS-48, a microbial cyclic polypeptide structurally and functionally related to mammalian NK-lysin. Proc Natl Acad Sci U S A 2000; 97(21): 11221-11226, https://doi.org/10.1073/pnas.210301097.

27. Bastos M. do C. de F., Coutinho B.G., Coelho M.L.V. Lysostaphin: a Staphylococcal bacteriolysin with potential clinical applications. Pharmaceuticals 2010; 3(4): 1139-1161, https://doi.org/10.3390/ph3041139.

28. Pickard J.M., Zeng M.Y., Caruso R., Núñez G. Gut microbiota: role in pathogen colonization, immune responses, and inflammatory disease. Immunol Rev 2017; 279(1): 70-89, https://doi.org/10.1111/imr.12567.
29. Chiu L., Bazin T., Truchetet M., Schaeverbeke T., Delhaes L., Pradeu T. Protective microbiota: from localized to long-reaching co-immunity. Front Immunol 2017; 8: 1678, https://doi.org/10.3389/fimmu.2017.01678.

30. Gillor O., Giladi I., Riley M.A. Persistence of colicinogenic Escherichia coli in the mouse gastrointestinal tract. BMC Microbiol 2009; 9(1): 165, https://doi. org/10.1186/1471-2180-9-165.

31. Zheng J., Gänzle M.G., Lin X.B., Ruan L., Sun M. Diversity and dynamics of bacteriocins from human microbiome. Environ Microbiol 2015; 17(6): 2133-2143, https:// doi.org/10.1111/1462-2920.12662.

32. Mignolet J., Fontaine L., Sass A., Nannan C., Mahillon J., Coenye T., Hols P. Circuitry rewiring directly couples competence to predation in the gut dweller Streptococcus salivarius. Cell Rep 2018; 22(7): 1627-1638, https://doi.org/10.1016/j.celrep.2018.01.055.

33. van der Ploeg J.R. Regulation of bacteriocin production in Streptococcus mutans by the quorum-sensing system required for development of genetic competence. J Bacteriol 2005; 187(12): 3980-3989, https://doi.org/10.1128/ jb.187.12.3980-3989.2005.

34. Gillor O., Ghazaryan L. Recent advances in bacteriocin application as antimicrobials. Recent Pat Antiinfect Drug Discov 2007; 2(2): 115-122, https://doi. org/10.2174/157489107780832613.

35. Majeed H., Lampert A., Ghazaryan L., Gillor O. The weak shall inherit: bacteriocin-mediated interactions in bacterial populations. PLoS One 2013; 21: 8(5): e63837, https://doi.org/10.1371/journal.pone.0063837.

36. Kommineni S., Bretl D.J., Lam V., Chakraborty R., Hayward M., Simpson P., Cao Y., Bousounis P., Kristich C.J., Salzman N.H. Bacteriocin production augments niche competition by enterococci in the mammalian gastrointestinal tract. Nature 2015; 29: 526(7575): 719-722, https://doi. org/10.1038/nature15524.

37. Hecht A.L., Casterline B.W., Earley Z.M., Goo Y.A., Goodlett D.R., Bubeck Wardenburg J. Strain competition restricts colonization of an enteric pathogen and prevents colitis. EMBO Rep 2016; 17(9): 1281-1291, https://doi. org/10.15252/embr.201642282.

38. Janek D., Zipperer A., Kulik A., Krismer B., Peschel A. High frequency and diversity of antimicrobial activities produced by nasal Staphylococcus strains against bacterial competitors. PLoS Pathog 2016; 4: 12(8): e1005812, https:// doi.org/10.1371/journal.ppat.1005812.

39. Bondarenko V.M., Suvorov A.N. Simbioticheskie enterokokki i problema enterokokkovoy opportunisticheskoy infektsii [Symbiotic enterococci and problem of enterococcal opportunistic infection]. Moscow; 2007.

40. Saleh F.A., El-Sayed E.M. Isolation and characterization of bacteriocins produced by Bifidobacterium lactis BB-12 and Bifidobacterium longum BB-46. In: 9th Egyptian conference for dairy science and technology. Cairo: Research Papers; 2004; p. 323-337.

41. Lee J.H., Li X., O'Sullivan D.J. Transcription analysis of a lantibiotic gene cluster from Bifidobacterium longum DJO10A. Appl Environ Microbiol 2011; 77(17): 5879-5887, https://doi.org/10.1128/aem.00571-11.

42. Djadouni F., Kihal M. Antimicrobial activity of lactic acid bacteria and the spectrum of their biopeptides against spoiling germs in foods. Braz Arch Biol Technol 2012; 55(3): 435-443, https://doi.org/10.1590/s1516-89132012000300015. 
43. Martinez F.C., Balciunas E.M., Converti A., Cotter P.D., de Souza Oliveira R.P. Bacteriocin production by Bifidobacterium spp. A review. Biotechnol Adv 2013; 31(4): 482-488, https://doi.org/10.1016/j.biotechadv.2013.01.010.

44. Kim Y.C., Tarr A.W., Penfold C.N. Colicin import into E. coli cells: a model system for insights into the import mechanisms of bacteriocins. Biochim Biophys Acta 2014; 1843(8): 1717-31, https://doi.org/10.1016/j. bbamcr.2014.04.010.

45. Solovyeva I.V., Belova I.V., Tochilina A.G., Grigoryeva G.I., Leonov A.V., Vorobyev G.E., Ivanova T.P., Zhirnov V.A. Prevention of formation of stable disbiotic conditions for students' microbiota of the gastrointestinal tract due to symbiotics. Medicinskij al'manah 2011; 2(15): 112-114.

46. Disbioz kishechnika. Rukovodstvo po diagnostike $i$ lecheniyu [Intestinal dysbiosis. Diagnosis and treatment manual]. Pod red. Suvorova A.N., Tkachenko E.I., Uspenskogo Yu.P. [Suvorov A.N., Tkachenko E.I., Uspenskiy Yu.P. (editors)]. Saint Petersburg: InformMed; 2013; 270 p.

47. Suvorov A., Simanenkov V., Gromova L., Kolodjieva V., Tsapieva A., Chernish A., Solovieva O., Ermolenko E. Enterococci as probiotics or autoprobiotics. In: Ivanova I. (editor). Prebiotics and probiotics potential for human health. Paisi Hilendarski, Sofia; 2011; p. 104-112.

48. Gonchar N.V., Aleshina L.A., Suvorov A.N. Probiotic strains of enterococci as a means of therapy and prophylaxis of intestinal diseases in children (review of literature). Eksperimental'naya i klinicheskaya gastroenterologiya 2013; 1 : 74-78.

49. Shchepitova N.E., Sycheva M.V., Kartashova O.L. Scrinning of enterococcus culture to create preporation of probiotic action. Vestnik Orenburgskogo gosudarstvennogo universiteta 2015; 13(188): 226-233.

50. Solovyeva I.V., Tochilina A.G., Belova I.V., Novikova N.A., Ivanova T.P. The lactobacillus biological properties. Prospects of express-methods nucleic acid amplification for the foods, food supplements and drugs on its basis quality control. Medial' 2014; 2(12): 29-44.

51. Shenderov B.A., Sinitsa A.V., Zakharchenko M.M. Metabiotiki: vchera, segodnya, zavtra [Metabiotics: yesterday, today, tomorrow]. Saint Petersburg: InformMed; 2017.

52. Dobson A., Cotter P.D., Ross R.P., Hill C. Bacteriocin production: a probiotic trait? Appl Environ Microbiol 2012; 78(1): 1-6, https://doi.org/10.1128/aem.05576-11.

53. Umu Ö.C.O., Rudi K., Diep D.B. Modulation of the gut microbiota by prebiotic fibres and bacteriocins. Microb Ecol Health Dis 2017; 28(1): 1348886, https://doi.org/10.1080/1651 2235.2017.1348886.

54. Aranha C.C., Gupta S.M., Reddy K.V. Assessment of cervicovaginal cytokine levels following exposure to microbicide nisin gel in rabbits. Cytokine 2008; 43(1): 63-70, https://doi.org/10.1016/j.cyto.2008.04.005.

55. Mathur H., O'Connor P.M., Hill C., Cotter P.D., Ross R.P. Analysis of anti-Clostridium difficile activity of thuricin $\mathrm{CD}$, vancomycin, metronidazole, ramoplanin, and actagardine, both singly and in paired combinations. Antimicrob Agents Chemother 2013; 57(6): 2882-2886, https://doi.org/10.1128/ aac.00261-13.

56. Ming L., Zhang Q., Yang L., Huang J.A. Comparison of antibacterial effects between antimicrobial peptide and bacteriocins isolated from Lactobacillus plantarum on three common pathogenic bacteria. Int J Clin Exp Med 2015; 8(4): 5806-5811.
57. Mathur H., Des F., Rea M.C., Cotter P.D., Hill C., Ross R.P. Bacteriocin-antimicrobial synergy: a medical and food perspective. Front Microbiol 2017; 8: 1205, https://doi. org/10.3389/fmicb.2017.01205.

58. Yuan J., Zhang Z.Z., Chen X.Z., Yang W., Huan L.D. Site-directed mutagenesis of the hinge region of nisin $Z$ and properties of nisin Z mutants. Appl Microbiol Biotechnol 2004; 64(6): 806-815, https://doi.org/10.1007/s00253-0041599-1.

59. Draper L.A., Cotter P.D., Hill C., Ross R.P. Lantibiotic resistance. Microbiol Mol Biol Rev 2015; 79(2): 171-191, https://doi.org/10.1128/mmbr.00051-14.

60. Modi K.D., Chikindas M.L., Montville T.J. Sensitivity of nisin-resistant Listeria monocytogenes to heat and the synergistic action of heat and nisin. Lett Appl Microbiol 2000; 30(3): 249-253, https://doi.org/10.1046/j.1472765x.2000.00708.x.

61. McBride S.M., Sonenshein A.L. Identification of a genetic locus responsible for antimicrobial peptide resistance in Clostridium difficile. Infect Immun 2011; 79(1): 167-176, https://doi.org/10.1128/iai.00731-10.

62. Suarez J.M., Edwards A.N., McBride S.M. The Clostridium difficile cpr locus is regulated by a noncontiguous two-component system in response to type $A$ and $B$ lantibiotics. J Bacteriol 2013; 195(11): 2621-2631, https://doi.org/10.1128/ jb.00166-13.

63. Khosa S., Alkhatib Z., Smits S.H. NSR from Streptococcus agalactiae confers resistance against nisin and is encoded by a conserved nsr operon. Biol Chem 2013; 394(11): 1543-1549, https://doi.org/10.1515/hsz-2013-0167.

64. Abi Khattar Z., Rejasse A., Destoumieux-Garzón D., Escoubas J.M., Sanchis V., Lereclus D., Givaudan A., Kallassy M., Nielsen-Leroux C., Gaudriault S. The dlt operon of Bacillus cereus is required for resistance to cationic antimicrobial peptides and for virulence in insects. J Bacteriol 2009; 191(22): 7063-7073, https://doi.org/ 10.1128/jb.00892-09.

65. Kovács M., Halfmann A., Fedtke I., Heintz M., Peschel A., Vollmer W., Hakenbeck R., Brückner R. A functional dlt operon, encoding proteins required for incorporation of D-alanine in teichoic acids in gram-positive bacteria, confers resistance to cationic antimicrobial peptides in Streptococcus pneumoniae. J Bacteriol 2006; 188(16): 5797-5805, https:// doi.org/10.1128/jb.00336-06.

66. Abachin E., Poyart C., Pellegrini E., Milohanic E., Fiedler F., Berche P., Trieu-Cuot P. Formation of D-alanyllipoteichoic acid is required for adhesion and virulence of Listeria monocytogenes. Mol Microbiol 2002; 43: 1-14, https:// doi.org/10.1046/j.1365-2958.2002.02723.x.

67. Kjos M., Nes I.F., Diep D.B. Mechanisms of resistance to bacteriocins targeting the mannose phosphotransferase system. Appl Environ Microbiol 2011; 77(10): 3335-3342, https://doi.org/10.1128/aem.02602-10.

68. Kommineni S., Kristich C.J., Salzman N.H. Harnessing bacteriocin biology as targeted therapy in the GI tract. Gut Microbes 2016; 7(6): 512-517, https://doi.org/10.1080/194909 76.2016.1233089.

69. Yang S.C., Lin C.H., Sung C.T., Fang J.Y. Antibacterial activities of bacteriocins: application in foods and pharmaceuticals. Front Microbiol 2014; 5: 241, https://doi. org/10.3389/fmicb.2014.00241.

70. Mendes C.A., Cordeiro J.A., Burdmann E.A. Prevalence and risk factors for acute kidney injury associated with 
parenteral polymyxin B use. Ann Pharmacother 2009; 43(12): 1948-1955, https://doi.org/10.1345/aph.1m277.

71. Abdelraouf K., Braggs K.H., Yin T., Truong L.D., $\mathrm{Hu}$ M., Tam V.H. Characterization of polymyxin B-induced nephrotoxicity: implications for dosing regimen design. Antimicrob Agents Chemother 2012; 56(9): 4625-4629, https:// doi.org/10.1128/aac.00280-12.

72. Ghobrial O., Derendorf H., Hillman J.D. Human serum binding and its effect on the pharmacodynamics of the lantibiotic MU1140. Eur J Pharm Sci 2010; 41(5): 658-664, https://doi.org/10.1016/j.ejps.2010.09.005.

73. Ghobrial O.G., Derendorf H., Hillman J.D. Development and validation of a LC-MS quantification method for the lantibiotic MU1140 in rat plasma. J Pharm Biomed Anal 2009; 49(4): 970-975, https://doi.org/10.1016/j.jpba.2008.12.022.

74. Ghobrial O., Derendorf H., Hillman J.D. Pharmacokinetic and pharmacodynamic evaluation of the lantibiotic MU1140. J Pharm Sci 2010; 99(5): 2521-2528, https://doi.org/10.1002/ jps.22015.

75. van Heel A.J., Montalban-Lopez M., Kuipers O.P. Evaluating the feasibility of lantibiotics as an alternative therapy against bacterial infections in humans. Expert Opin Drug Metab Toxicol 2011; 7(6): 675-680, https://doi.org/10.15 17/17425255.2011.573478.

76. Caballero Gómez N., Abriouel H., Grande M.J., Pérez Pulido R., Gálvez A. Combined treatments of enterocin AS-48 with biocides to improve the inactivation of methicillin-sensitive and methicillin-resistant Staphylococcus aureus planktonic and sessile cells. Int J Food Microbiol 2013; 163(2-3): 96-100, https://doi.org/10.1016/j.ijfoodmicro.2013.02.018.

77. Sharma A., Srivastava S. Anti-Candida activity of twopeptide bacteriocins, plantaricins (PIn E/F and J/K) and their mode of action. Fungal Biol 2014; 118(2): 264-275, https://doi. org/10.1016/j.funbio.2013.12.006.

78. Cavera V.L., Volski A., Chikindas M.L. The natural antimicrobial subtilosin $A$ synergizes with lauramide arginine ethyl ester (LAE), $\varepsilon$-poly-l-lysine (polylysine), clindamycin phosphate and metronidazole, against the vaginal pathogen Gardnerella vaginalis. Probiotics Antimicrob Proteins 2015; 7(2): 164-171, https://doi.org/10.1007/s12602-014-9183-1.

79. Brumfitt W., Salton M.R., Hamilton-Miller J.M. Nisin, alone and combined with peptidoglycan-modulating antibiotics: activity against methicillin-resistant Staphylococcus aureus and vancomycin-resistant enterococci. J Antimicrob Chemother 2002; 50(5): 731-734, https://doi.org/10.1093/jac/dkf190.

80. Draper L.A., Cotter P.D., Hill C., Ross R.P. The two peptide lantibioticlacticin 3147 acts synergistically with polymyxin to inhibit gram negative bacteria. BMC Microbiol 2013; 13(1): 212, https://doi.org/10.1186/1471-2180-13-212.

81. LeBel G., Piché F., Frenette M., Gottschalk M., Grenier D. Antimicrobial activity of nisin against the swine pathogen Streptococcus suis and its synergistic interaction with antibiotics. Peptides 2013; 50: 19-23, https://doi.org/10.1016/j. peptides.2013.09.014.

82. Tong Z., Zhang L., Ling J., Jian Y., Huang L., Deng D. $A n$ in vitro study on the effect of free amino acids alone or in combination with nisin on biofilms as well as on planktonic bacteria of Streptococcus mutans. PLoS One 2014; 9(6): e99513, https://doi.org/10.1371/journal.pone.0099513.

83. Tong Z., Zhang Y., Ling J., Ma J., Huang L., Zhang L. In vitro study on the effects of nisin on the antibacterial activities of 18 antibiotics against Enterococcus faecalis. PLoS One 2014; 9(2): e89209, https://doi.org/10.1371/journal.pone.0089209.
84. Vaillancourt K., LeBel G., Frenette M., Gottschalk M., Grenier D. Suicin 3908 , a new lantibiotic produced by a strain of Streptococcus suis serotype 2 isolated from a healthy carrier pig. PLoS One 2015; 10(2): e0117245, https://doi.org/10.1371/ journal.pone. 0117245 .

85. Flemming H.C., Wingender J. The biofilm matrix. Nat Rev Microbiol 2010; 8(9): 623-633, https://doi.org/10.1038/ nrmicro2415.

86. Mah T.F., O'Toole G.A. Mechanisms of biofilm resistance to antimicrobial agents. Trends Microbiol 2001; 9(1): 34-39, https://doi.org/10.1016/s0966-842x(00)01913-2.

87. Davies D. Understanding biofilm resistance to antibacterial agents. Nat Rev Drug Discov 2003; 2(2): 114122, https://doi.org/10.1038/nrd1008.

88. Mataraci E., Dosler S. In vitro activities of antibiotics and antimicrobial cationic peptides alone and in combination against methicillin-resistant Staphylococcus aureus biofilms. Antimicrob Agents Chemother 2012; 56(12): 6366-6371, https://doi.org/10.1128/aac.01180-12.

89. Dosler S., Mataraci E. In vitro pharmacokinetics of antimicrobial cationic peptides alone and in combination with antibiotics against methicillin resistant Staphylococcus aureus biofilms. Peptides 2013; 49: 53-58, https://doi.org/10.1016/j. peptides.2013.08.008.

90. Algburi A., Volski A., Chikindas M.L. Natural antimicrobials subtilosin and lauramide arginine ethyl ester synergize with conventional antibiotics clindamycin and metronidazole against biofilms of Gardnerella vaginalis but not against biofilms of healthy vaginal lactobacilli. Pathog Dis 2015; 73: ftv018, https://doi.org/10.1093/femspd/ftv018.

91. Ceotto-Vigoder H., Marques S.L., Santos I.N., Alves M.D., Barrias E.S., Potter A., Alviano D.S., Bastos M.C. Nisin and lysostaphin activity against preformed biofilm of Staphylococcus aureus involved in bovine mastitis. J Appl Microbiol 2016; 121(1): 101-114, https://doi.org/10.1111/ jam.13136.

92. Rodríguez-Rubio L., García P., Rodríguez A., Billington C., Hudson J.A., Martínez B. Listeria phages and coagulin C23 act synergistically to kill Listeria monocytogenes in milk under refrigeration conditions. Int $J$ Food Microbiol 2015; 205: 68-72, https://doi.org/10.1016/j. ijfoodmicro.2015.04.007.

93. Martínez B., Obeso J.M., Rodríguez A., García P. Nisinbacteriophage cross resistance in Staphylococcus aureus. Int J Food Microbiol 2008; 122(3): 253-258, https://doi. org/10.1016/j.ijfoodmicro.2008.01.011.

94. Nascimento J.G., Guerreiro-Pereira M.D., Costa S F., São-José C., Santos M.A. Nisin-triggered activity of Lys44, the secreted endolysin from Oenococcus oeni phage fOg44. J Bacteriol 2008; 190(1): 457-461, https://doi.org/10.1128/ jb.01195-07.

95. Obeso J.M., Martínez B., Rodríguez A., García P. Lytic activity of the recombinant staphylococcal bacteriophage phiH5 endolysin active against Staphylococcus aureus in milk. Int J Food Microbiol 2008; 128(2): 212-218, https://doi. org/10.1016/j.ijfoodmicro.2008.08.010.

96. García P., Martínez B., Rodríguez L., Rodríguez A. Synergy between the phage endolysin LysH5 and nisin to kill Staphylococcus aureus in pasteurized milk. Int J Food Microbiol 2010; 141: 151-155, https://doi.org/10.1016/j. ijfoodmicro.2010.04.029.

97. Dajcs J.J., Thibodeaux B.A., Girgis D.O., Shaffer M.D., Delvisco S.M., O'Callaghan R.J. Immunity to Iysostaphin and 
its therapeutic value for ocular MRSA infections in the rabbit. Invest Ophthalmol Vis Sci 2002; 43(12): 3712-3716.

98. Becker S.C., Foster-Frey J., Donovan D.M. The phage K lytic enzyme LysK and lysostaphin act synergistically to kill MRSA. FEMS Microbiol Lett 2008; 287(2): 185-191, https:// doi.org/10.1111/j.1574-6968.2008.01308.x.

99. Mathur H., Rea M.C., Cotter P.D., Hill C., Ross R.P. The sactibiotic subclass of bacteriocins: an update. Curr Protein Pept Sci 2015; 16(6) 549-558, https://doi.org/10.2174/138920 3716666150515124831.

100. Blinkova L.P., Mashentseva N.G., Khorolsky V.V.,
Gorobets O.B., Dorofeeva E.S. Biotechnological conditions of the synthesis of bacteriocins. Zhurnal mikrobiologii epidemiologii i immunobiologii 2006; 2: 83-89.

101. Pei J., Yuan Y., Yue T. Characterization of bacteriocin bificin C6165: a novel bacteriocin. J Appl Microbiol 2013; 114(5): 1273-1284, https://doi.org/10.1111/ jam.12145.

102. Bédard F., Biron E. Recent progress in the chemical synthesis of class II and S-glycosylated bacteriocins. Front Microbiol 2018; 9: 1048, https://doi.org/10.3389/ fmicb.2018.01048. 